\title{
CHANGES IN CARBOHYDRATE METABOLISM AND ADIPOCYTOKINES UNDER THE INFLUENCE OF TREATMENT OF PATIENTS WITH ALCOHOLIC CIRRHOSIS OF THE LIVER IN COMBINATION WITH OBESITY USING ADAMETHIONINUM AND ARGININE GLUTAMATE
}

Introduction. Alcohol-related liver cirrhosis is one of the leading causes of hospitalization and disability in patients with gastrointestinal disease.

The aim of the study - to learn the effectiveness of treatment of patients with alcoholic liver cirrhosis (ALC) combined with obesity depending on the stage of decompensation using ademethionine and arginine glutamate.

Research Methods. 215 patients, diagnosed with ALC, took part in the study, including 66 women and 149 men. 109 people had ALC with obesity and 106 people had ALC without obesity. Patients were divided into subgroups depending on the stage of decompensation according to Child-Pugh. Depending on the treatment protocol (b protocol basic therapy, $h$ protocol - basic therapy in combination with ademethionine and arginine glutamate), all patients were divided into subgroups.

Results and Discussion. In this study, the values of carbohydrate metabolism, adiponectin and leptin were used to evaluate the effectiveness of a three-month treatment regimen with ademethionine and arginine glutamate in patients with ALC in combination with obesity. Obese patients with ALC have a more severe course of the disease, accompanied by more pronounced clinical manifestations, impaired carbohydrate metabolism and imbalance of leptin and adiponectin levels. The inclusion of ademethionine and arginine glutamate in the treatment regimen for 3 months allowed to improve the general condition of patients, their clinical and laboratory parameters and reduce the rate of disease progression, which is reflected in improved carbohydrate metabolism, leptin and adiponectin and reduced indicators of the severity scale according to Child-Pugh and the 3-month MELD mortality score.

Conclusions. Inclusion of ademethionine and arginine glutamate in the complex treatment of patients with ALC in combination with obesity helps to reduce insulin resistance, improve leptin and adiponectin. In patients with ALC in combination with obesity, the inclusion in the complex treatment of ademethionine and arginine glutamate helps to improve the course of the disease according to the indicators of the severity scale using the Child-Pugh and MELD scales.

KEY WORDS: alcoholic liver disease; liver cirrhosis; obesity; adipocytokines; carbohydrate metabolism.

INTRODUCTION. The steady increase in metabolic disorders among the world's population, associated with the development of obesity and its consequences, attracts special attention of scientists. The problem affects about a quarter of the adult population due to certain changes in society, including a high prevalence of sedentary lifestyles, low physical activity, excessive consumption of high-calorie foods with insufficient energy expenditure and unhealthy food, which leads to unbalanced diet [1-3]. The prevalence of metabolic disorders among the population of wealthy countries in people with normal weight is also high. In addition, there is currently no clear nomenclature of liver diseases caused by metabolic factors, and, as a result, there

(c) N. R. Matkovska, 2020 is no defined algorithm for the management of such patients [4-6]. With regard to liver damage, an international group of experts proposed to clarify the definitions and criteria for assessing metabolic dysfunction associated with fatty liver disease [7-9]. As the pathogenetic mechanisms underlying the development of this condition are associated with systemic metabolic dysfunction, metabolic dysfunction, which is associated with fatty liver disease, is often perceived as an independent disease with inherent criteria that do not depend on the amount of alcohol consumed and therefore can be used for patients under any clinical conditions [10-12]. Liver cirrhosis (LC) on the background of metabolic dysfunction, associated with fatty liver disease, includes the following criteria of confirmation of 
metabolic risk factors: waist circumference $\geq 102 / 88 \mathrm{~cm}$ in men and women of Caucasian race or $\geq 90 / 80 \mathrm{~cm}$ in men and women of Asian race); blood pressure $\geq 130 / 85 \mathrm{~mm} \mathrm{Hg}$ or specific drug treatment; plasma triglycerides $\geq 150 \mathrm{mg} / \mathrm{dL}$ ( $\geq 1.70 \mathrm{mmol} / \mathrm{l}$ ) or specific drug treatment; plasma $\mathrm{HDL}$ cholesterol $<40 \mathrm{mg} / \mathrm{dL}(<1.0 \mathrm{mmol} / \mathrm{l})$ for men and $<50 \mathrm{mg} / \mathrm{dL}$ ( $<1.3 \mathrm{mmol} / \mathrm{l}$ ) for women or specific drug treatment; signs of prediabetes; evaluation of the homeostasis model for the evaluation of insulin resistance $\geq 2.5$; high-sensitivity plasma C-reactive protein level $>2 \mathrm{mg} / \mathrm{l}$ ), documented data on steatosis by imaging or previous liver biopsy (if performed) taking into account the possible dual etiology of the disease - a combination of alcohol abuse [13-15].

Alcohol-related LC is one of the leading causes of hospitalization and disability in patients with gastrointestinal disease. The mortality rate among such people is 15-25\% [16]. With combined pathology, the prognosis for patients deteriorates. Therefore, we are looking for ways to prevent the progression, complications of $\mathrm{LC}$ and improve the quality of life of such patients [17-19].

The aim of the study was to learn the effectiveness of treatment of patients with alcoholic liver cirrhosis (ALC) combined with obesity depending on the stage of decompensation using ademethionine and arginine glutamate.

RESEARCH METHODS. 215 patients, diagnosed with alcoholic liver cirrhosis (ALC), took part in the study, including 66 women and 149 men aged (48.1 \pm 9.7$)$ years and a median disease duration $(5.8 \pm 2.6)$ years. 109 people had ALC with obesity (group I) and 106 people had ALC without obesity (group II). Patients were divided into subgroups depending on the stage of decompensation according to Child-Pugh: class A-group IA $(n=40)$, class $B$ - group IB $(n=39)$, class $C$ - group IC $(n=30)$ and IIA $(n=39)$, IIB $(n=36)$, IIC $(n=31)$ groups, respectively; and also depending on the treatment protocol all patients were divided into subgroups (b protocol - basic therapy, h protocol - basic therapy in combination with intravenous administration of ademethionine and subsequent oral administration of ademethionine and arginine glutamate): patients receiving basic therapy were included in IAb $(n=19), I B b(n=20), I C b(n=15), I I A b$ $(n=22), I I B b(n=18), I I C b(n=16)$ groups; patients who additionally received ademethionine and arginine glutamate were included in IAh $(n=21)$, IBh $(n=19)$, ICh ( $n=15)$ Ta IIAh ( $n=17)$, IIBh $(n=18)$, IICh $(n=15)$ groups.

Groups Ih and IIAh, in addition to the basic treatment, received intravenously $500 \mathrm{mg}$ of ademethionine per day during two weeks, followed by oral administration of $500 \mathrm{mg}$ of ademethionine and $1500 \mathrm{mg}$ of arginine glutamate per day for 12 weeks.

Groups IBh and IIBh, in addition to the basic treatment, received intravenously $1000 \mathrm{mg}$ of ademethionine per day for two weeks, followed by oral administration of $1000 \mathrm{mg}$ of ademethionine and $3000 \mathrm{mg}$ of arginine glutamate for 12 weeks.

Groups ICh and IICh, in addition to their basic treatment, received intravenously $1000 \mathrm{mg}$ of ademethionine per day for two weeks, followed by oral administration of $1500 \mathrm{mg}$ of ademethionine and $4500 \mathrm{mg}$ of arginine glutamate per day for 12 weeks.

Diagnosis was verified using clinical and laboratory-instrumental methods in accordance with the order of the Ministry of Health of Ukraine No. 826 dated November 6, 2014, adapted clinical guidelines "Non-Alcoholic Fatty Liver Disease", 2014, adapted clinical guidelines "Alcoholic Liver Disease", 2014, adapted clinical guidelines " Liver Cirrhosis, 2017 (State Expert Centre of the Ministry of Health of Ukraine, Ukrainian Gastroenterology Association, Kyiv), recommendations of the European Association for the Study of Liver, Diabetes and Obesity (EASLEASD-EASO, 2016).

Exclusion criteria were liver cirrhosis of the viral, toxic and autoimmune genesis, metabolic diseases of the liver, oncological diseases, and the lack of individual consent of the patient to conduct the study. All patients were matched according to age and sex. The research was carried out in accordance with the ethical principles of conducting scientific research and principles of the Helsinki Declaration.

The carbohydrate metabolism was evaluated for immunoreactive insulin (IRI) indicatros, glycosylated haemoglobin (HbA1c), HOMA-IR indexes (calculated using the formula HOMA-IR = (glycemia in the fasted state, $\mathrm{mmol} / /^{\star}$ insulin in the fasted state $(\mathrm{mcU} / \mathrm{ml})) / 22.5)$ and QUICKI (www.mdapp.co/insulin-sensitivity-quicki-calculator-324). The level of leptin and adiponectin was determined by immunoassay using Human Leptin ELISA (Biovendor, Czech Republic) and Human Adiponectin ELISA kit (Biovendor, Czech Republic) respectively. The severity of the LC was assessed using the ChildPugh score and the MELD score (Mayo Endstage Liver Disease, 2001). The control group consisted of 20 healthy individuals, who were age and gender matched. Assessment of patients was performed before and after 3 months from the beginning of treatment.

Statistical processing of the obtained results was carried out using the software package Statistica v. 12.0 (StatSoft, USA, trial) and Microsoft Excel. The average values are presented in the form $(M \pm m)$, where " $M$ " is the average value of the 
indicator, " $m$ " is the standard error of the average. Student's t-test was used to determine the significance of differences between groups in a distribution close to normal. Differences at $p<0.05$ were considered statistically significant.

The study is carried out according to the plan of scientific works of Ivano-Frankivsk National Medical University and is a fragment of research work: "Diseases of internal organs in modern conditions, with combined pathology and lesions of target organs: features of the course, diagnosis and treatment", number of state registration: $0115 \cup 000995$.

RESULTS AND DISCUSSION. Patients with signs of astheno-vegetative, painful, dyspeptic, hepatorenal, hepatopulmonary syndromes, jaundice, drug-induced ascites, manifestations of hepatic encephalopathy were more common in group I of the corresponding classes, which was accompanied by a more severe course of the ALC according to the Child-Pugh and MELD scores. In patients of both groups, they increased with increasing ALC decompensation. However, in patients of group I these values were higher compared to group II by $7.23 \%$ and $28.42 \%, 13.62 \%$ and $17.14 \%, 14.62 \%$ and $18.57 \%$ of classes A, B, C, respectively $(p<0.05)$, (Tables $1-3)$.

These results indicate a more severe course and more pronounced progression of liver failure in patients with a combination of ALD and obesity due to a more pronounced increase in inflammatorynecrotic process and fibrosis in the liver and accompanied by significant systemic changes in blood flow, more severe systemic immunoinflammatory response, which ultimately leads to the development of multiple organ failure with fatal consequences.

The specific feature of carbohydrate metabolism was a significant increase in IRI in patients of group I $(p<0.05)$. It was $3.78,4.63$ and 4.06 times higher than that of classes A, B and C of group II, respectively. The HOMA-IR index in persons of group I significantly exceeded this indicator of group II of classes A, B and C by 4.58, 4.11 and 3.26 times, respectively $(p<0.05)$. The QUICKI index in patients of group II also significantly exceeded this indicator in patients of group I in 1.68, 1.67 and 1.22 times of classes A, B and C, respectively $(p<0.05)$. The level of $\mathrm{HbA} 1 \mathrm{c}$ in patients of group I also significantly exceeded this figure in patients of group II by 1.28 and 1.25 times of classes A and B, respectively $(p<0.05)$, but there was no significant difference between groups I and II of class C ( $p>0.05)$.

The imbalance of adipocytokines was more pronounced in patients of group I. In particular, the content of leptin in the blood of patients of group I was higher compared to that of patients of group II and of $A$ and $B$ classes according to Child-Pugh in 2.25 and 1.75 times, respectively $(p<0.05)$. In both Childe-Pugh class $C$ groups, leptin levels did not differ significantly $(p>0.05)$. The content of adiponectin in patients of group I was lower in comparison with patients of group II of $A$ and $B$ classes according to Child-Pugh in 3.18 and 2.82 times, respectively $(p<0.05)$. No significant difference between adiponectin levels in both groups of class $C$ was found ( $p>0.05$ ), and in patients of groups I and II its level increased by 4.91 and 1.72 times, respectively, compared with class $B$. This indicates a significant increase in the adiponectin level in patients with decompensated LC, which is accompanied by catabolic processes, a decrease in somatic protein, depletion of fat depots, the development of cachexia.

The correlations between adiponectin, carbohydrate metabolism and leptin levels in patients of group I were as follows: for adiponectin --0.74 , -0.62 and -0.64 for $A, B$ and $C$ classes, respectively; for IRI $--0.69,-0.53$ and -0.49 for $A, B$ and $C$ classes, respectively; for HOMA-IR - $-0.54,-0.41$ and -0.33 for $A, B$ and $C$ classes, respectively; for QUICKI $-0.63,0.69$ and 0.74 for $A, B$ and $C$ classes, respectively; for HbAlc $--0.35,-0.33$ and -0.31 for A, B and C classes, respectively. Correlations between adiponectin levels and carbohydrate metabolism in patients of group I were for IRI -0.45 , 0.38 and 0.31 for $A, B$ and $C$ classes, respectively; for HOMA-IR - 0.36, 0.31 and 0.27 for A, B and C classes, respectively; for QUICKI - $-0.42,-0.38$ and -0.37 for $A, B$ and $C$ classes, respectively; for $\mathrm{HbAlc}-0.31,0.27$ and 0.25 for $\mathrm{A}, \mathrm{B}$ and $\mathrm{C}$ classes, respectively. The relationship between adiponectin levels, disease severity and the MELD score was more pronounced in patients of group I.

A correlation between leptin, adiponectin levels, Child-Pugh and MELD scores showed a stronger relationship in patients of group I with increased decompensation. The correlation between leptin level, Child-Pugh and MELD scores was as follows: for Child-Pugh $-r=0.72, r=-0.58, r=-0,44$, and for MELD - $r=-0.66, r=-0.61, r=-0.68$ for classes A, B, $C$, respectively. The relationship between the level of adiponectin and the severity of the disease and the MELD score was for the Child-Pugh index $r=0.69, r=-0.49, r=0.67$, and for the MELD score $r=0.73, r=0.52, r=0.34$ for classes $A, B, C$, respectively.

Three months after the prescribed course of treatment, clinical and laboratory manifestations improved in most patients receiving the $\mathrm{h}$ protocol, whereas in patients with the $b$ protocol, deterioration was observed, especially at the stages of subcompensation and decompensation. In patients re- 
ceiving basic treatment, the Child-Pugh and MELD scores deteriorated, indicating further disease progression and, consequently, a worsening of the mortality prognosis. Within 3 months from the beginning of treatment, 3 people died in group $\mathrm{ICb}$ and 2 people - in group IICb due to deterioration of patients' condition and the development of complications (in 2 patients of group $\mathrm{IICb}$ and 1 patient

Table 1 - Dynamics of adipocytokines levels, carbohydrate metabolism, severity and prognostic MELD score in patients with alcoholic liver cirrhosis with stage $A$ by Child-Pugh, depending on the combination with obesity, $M \pm m$

\begin{tabular}{|c|c|c|c|c|c|}
\hline \multirow{3}{*}{ Values } & \multirow{3}{*}{$\begin{array}{c}\text { Control, } \\
n=20\end{array}$} & \multicolumn{4}{|c|}{ ALC with obesity } \\
\hline & & \multicolumn{2}{|c|}{$\mathrm{IAb}, \mathrm{n}=19$} & \multicolumn{2}{|c|}{ IAh, n=21 } \\
\hline & & $\begin{array}{c}\text { Before } \\
\text { treatment }\end{array}$ & $\begin{array}{l}\text { After } 3 \text { month } \\
\text { treatment }\end{array}$ & $\begin{array}{c}\text { Before } \\
\text { treatment }\end{array}$ & $\begin{array}{c}\text { After } 3 \text { month } \\
\text { treatment }\end{array}$ \\
\hline Adiponectin, $\mu \mathrm{g} / \mathrm{ml}$ & $8.46 \pm 0.11$ & $2.86 \pm 0.15^{\star}$ & $2.67 \pm 0.18^{\star \#}$ & $2.79 \pm 0.16^{\star \bullet}$ & $5.58 \pm 0.14^{\star}$ \\
\hline Leptin, ng/ml & $7,92 \pm 0,28$ & $21.72 \pm 0.58^{\star}$ & $22.52 \pm 0.66^{\star \#}$ & $21.43 \pm 0.62 * *$ & $12.37 \pm 0.52^{\star}$ \\
\hline IRI, mcod/l & $5.89 \pm 0.32$ & $23.53 \pm 1.46^{*}$ & $25.81 \pm 1.22^{\star \#}$ & $24.65 \pm 1.34^{\star \bullet}$ & $6.36 \pm 0.38$ \\
\hline HOMA-IR & $1.05 \pm 0.06$ & $5.39 \pm 0.15^{\star}$ & $5.57 \pm 0.11^{\star \#}$ & $5.43 \pm 0.12^{\star \bullet}$ & $1.11 \pm 0.09$ \\
\hline QUICKI & $0.681 \pm 0.004$ & $0,374 \pm 0,007^{*}$ & $0.368 \pm 0.005^{\star *}$ & $0.372 \pm 0.006^{\star \bullet}$ & $0.664 \pm 0.006$ \\
\hline HbA1c, \% & $4.63 \pm 0.18$ & $6.33 \pm 0.14^{*}$ & $6.69 \pm 0.16^{\star \#}$ & $6.35 \pm 0.12^{\star \bullet}$ & $4.71 \pm 0.15$ \\
\hline Child-Pugh score & - & $5.76 \pm 0.11^{\star}$ & $5,94 \pm 0,12^{\star \#}$ & $5,81 \pm 0,09 * \bullet$ & $5,32 \pm 0,11$ \\
\hline MELD score & - & $13.64 \pm 0.92^{*}$ & $14.79 \pm 0.95^{\star \#}$ & $13.47 \pm 0.84^{* \bullet}$ & $8.17 \pm 0.75$ \\
\hline
\end{tabular}

Continuation of Table 1

\begin{tabular}{|c|c|c|c|c|c|}
\hline \multirow{3}{*}{ Values } & \multirow{3}{*}{$\begin{array}{c}\text { Control, } \\
n=20\end{array}$} & \multicolumn{4}{|c|}{ ALC } \\
\hline & & \multicolumn{2}{|c|}{ IIAb, $\mathrm{n}=22$} & \multicolumn{2}{|c|}{ IIAh, $\mathrm{n}=17$} \\
\hline & & $\begin{array}{l}\text { Before } \\
\text { treatment }\end{array}$ & $\begin{array}{l}\text { After } 3 \text { month } \\
\text { treatment }\end{array}$ & $\begin{array}{c}\text { Before } \\
\text { treatment }\end{array}$ & $\begin{array}{l}\text { After } 3 \text { month } \\
\text { treatment }\end{array}$ \\
\hline Adiponectin, $\mu \mathrm{g} / \mathrm{ml}$ & $8.46 \pm 0.11$ & $8.94 \pm 0.16$ & $9.22 \pm 0.12^{\#}$ & $8.86 \pm 0.15^{\bullet}$ & $8.51 \pm 0.13$ \\
\hline Leptin, ng/ml & $7,92 \pm 0,28$ & $9.72 \pm 0.46$ & $10.27 \pm 0.41^{\#}$ & $9.86 \pm 0.53^{\circ}$ & $8.12 \pm 0.37$ \\
\hline IRI, mcod/I & $5.89 \pm 0.32$ & $6.43 \pm 0.25$ & $6.51 \pm 0.11^{\#}$ & $6.41 \pm 0.12^{\bullet}$ & $6.05 \pm 0.11$ \\
\hline HOMA-IR & $1.05 \pm 0.06$ & $1.21 \pm 0.06$ & $1.28 \pm 0.03^{\#}$ & $1.20 \pm 0.05^{\bullet}$ & $1.08 \pm 0.04$ \\
\hline QUICKI & $0.681 \pm 0.004$ & $0.627 \pm 0.005$ & $0.619 \pm 0.007^{\#}$ & $0.628 \pm 0.004^{\bullet}$ & $0.673 \pm 0.006$ \\
\hline HbA1c, \% & $4.63 \pm 0.18$ & $4.96 \pm 0.18$ & $5.17 \pm 0.13^{\#}$ & $4.99 \pm 0.16^{\bullet}$ & $4.67 \pm 0.11$ \\
\hline Child-Pugh score & - & $5,38 \pm 0,08$ & $5,51 \pm 0,07^{\#}$ & $5,39 \pm 0,09 \bullet$ & $5,19 \pm 0,08$ \\
\hline MELD score & - & $10.36 \pm 0.71$ & $10.94 \pm 0.68^{\#}$ & $10.54 \pm 0.86^{\bullet}$ & $7.41 \pm 0.57$ \\
\hline
\end{tabular}

Notes.

1. * - probability of difference of values between groups I and II $(p<0.05)$.

2. - probability of differences of values before and after treatment $(p<0.05)$.

3. \# - probability of differences of values between groups A and Ah with treatment protocols $(p<0.05)$.

Table 2 - Dynamics of adipocytokines levels, carbohydrate metabolism, severity and prognostic MELD score in patients with alcoholic liver cirrhosis with stage $B$ by Child-Pugh, depending on the combination with obesity, $M \pm m$

\begin{tabular}{|c|c|c|c|c|c|}
\hline \multirow{3}{*}{ Values } & \multirow{3}{*}{$\begin{array}{c}\text { Control, } \\
n=20\end{array}$} & \multicolumn{4}{|c|}{ ALC with obesity } \\
\hline & & \multicolumn{2}{|c|}{$\mathrm{IBb}, \mathrm{n}=20$} & \multicolumn{2}{|c|}{ IBh, $n=19$} \\
\hline & & $\begin{array}{l}\text { Before } \\
\text { treatment }\end{array}$ & $\begin{array}{l}\text { After } 3 \text { month } \\
\text { treatment }\end{array}$ & $\begin{array}{l}\text { Before } \\
\text { treatment }\end{array}$ & $\begin{array}{l}\text { After } 3 \text { month } \\
\text { treatment }\end{array}$ \\
\hline Adiponectin, $\mu \mathrm{g} / \mathrm{ml}$ & $8.46 \pm 0.11$ & $3.29 \pm 0.06^{* \bullet}$ & $3.04 \pm 0.08^{\star \#}$ & $3.24 \pm 0.09 * \bullet$ & $5.34 \pm 0.06^{*}$ \\
\hline Leptin, ng/ml & $7.92 \pm 0.28$ & $15.47 \pm 0.82^{\star \bullet}$ & $18.67 \pm 0.94^{\star \#}$ & $15.52 \pm 0.76^{\star \bullet}$ & $10.21 \pm 0.88^{\star}$ \\
\hline IRI, mcod/l & $5.89 \pm 0.32$ & $31.37 \pm 1.25^{\star \bullet}$ & $34.11 \pm 1.18^{\star \#}$ & $31.43 \pm 1.22^{\star \bullet}$ & $17.32 \pm 1.16^{*}$ \\
\hline HOMA-IR & $1.05 \pm 0.06$ & $7.12 \pm 0.21^{\star \bullet}$ & $7.54 \pm 0.17^{\text {*\# }}$ & $7.15 \pm 0.19 * \bullet$ & $2.97 \pm 0.15^{\star}$ \\
\hline QUICKI & $0.681 \pm 0.004$ & $0.348 \pm 0.004^{\star \bullet}$ & $0.339 \pm 0.003^{\star \#}$ & $0.349 \pm 0.005^{\star \bullet}$ & $0.652 \pm 0.0055^{\star}$ \\
\hline HbA1c, \% & $4.63 \pm 0.18$ & $6.38 \pm 0.14^{\star \bullet}$ & $6.71 \pm 0.11^{\text {*\# }}$ & $6.42 \pm 0.17^{\star \bullet}$ & $4.97 \pm 0.15^{\star}$ \\
\hline Child-Pugh score & - & $8.73 \pm 0.19 * \bullet$ & $9.17 \pm 0.15^{\star \#}$ & $8.82 \pm 0.12^{\star \bullet}$ & $5.47 \pm 0.14$ \\
\hline MELD score & - & $19.74 \pm 0.72^{\star \bullet}$ & $21.86 \pm 1.15^{\star \#}$ & $19.95 \pm 1.12^{\star \bullet}$ & $8.65 \pm 0.43$ \\
\hline
\end{tabular}


Continuation of Table 2

\begin{tabular}{|c|c|c|c|c|c|}
\hline \multirow{3}{*}{ Values } & \multirow{3}{*}{$\begin{array}{c}\text { Control, } \\
n=20\end{array}$} & \multicolumn{4}{|c|}{ ALC } \\
\hline & & \multicolumn{2}{|c|}{ IIBb, $\mathrm{n}=18$} & \multicolumn{2}{|c|}{ IIBh, $n=18$} \\
\hline & & $\begin{array}{l}\text { Before } \\
\text { treatment }\end{array}$ & $\begin{array}{c}\text { After } 3 \text { month } \\
\text { treatment }\end{array}$ & $\begin{array}{c}\text { Before } \\
\text { treatment }\end{array}$ & $\begin{array}{c}\text { After } 3 \text { month } \\
\text { treatment }\end{array}$ \\
\hline Adiponectin, $\mu \mathrm{g} / \mathrm{ml}$ & $8.46 \pm 0.11$ & $9.18 \pm 0.07^{\bullet}$ & $9.92 \pm 0.12^{\#}$ & $9.23 \pm 0.14^{\bullet}$ & $8.65 \pm 0.11$ \\
\hline Leptin, ng/ml & $7.92 \pm 0.28$ & $8.87 \pm 0.28$ & $9.13 \pm 0.19^{\#}$ & $8.84 \pm 0.21^{\bullet}$ & $8.13 \pm 0.29$ \\
\hline IRI, mcod/I & $5.89 \pm 0.32$ & $6.68 \pm 0.27$ & $6.98 \pm 0.19^{\#}$ & $6.72 \pm 0.14^{\bullet}$ & $6.25 \pm 0.18$ \\
\hline HOMA-IR & $1.05 \pm 0.06$ & $1.84 \pm 0.09$ & $1.96 \pm 0.07^{\#}$ & $1.81 \pm 0.11^{\bullet}$ & $1.53 \pm 0.08$ \\
\hline QUICKI & $0.681 \pm 0.004$ & $0.582 \pm 0.003$ & $0.578 \pm 0.004$ & $0.581 \pm 0.003^{\bullet}$ & $0.638 \pm 0.007$ \\
\hline HbA1c, \% & $4.63 \pm 0.18$ & $5.09 \pm 0.16$ & $5.23 \pm 0.21$ & $5.16 \pm 0.12^{\bullet}$ & $4.71 \pm 0.13$ \\
\hline Child-Pugh score & - & $7.69 \pm 0.17^{\bullet}$ & $8.08 \pm 0.16^{\#}$ & $7.81 \pm 0.11^{\bullet}$ & $5.24 \pm 0.13$ \\
\hline MELD score & - & $16.76 \pm 1.16^{\bullet}$ & $19.64 \pm 1.27^{\#}$ & $16.98 \pm 1.20^{\bullet}$ & $7.92 \pm 0.56$ \\
\hline
\end{tabular}

Notes.

1. * - probability of difference of values between groups I and II $(p<0.05)$.

2. - probability of differences of values before and after treatment $(p<0.05)$.

3. \# - probability of differences of values between groups A and Ah with treatment protocols $(p<0.05)$.

Table 3 - Dynamics of adipocytokines levels, carbohydrate metabolism, severity and prognostic MELD score in patients with alcoholic liver cirrhosis

with stage $C$ by Child-Pugh, depending on the combination with obesity, $M \pm m$

\begin{tabular}{|c|c|c|c|c|c|}
\hline \multirow[b]{3}{*}{ Values } & \multirow{3}{*}{$\begin{array}{l}\text { Control, } \\
n=20\end{array}$} & \multicolumn{4}{|c|}{ ALC with obesity } \\
\hline & & \multicolumn{2}{|c|}{$\mathrm{ICb}$} & \multicolumn{2}{|c|}{ ICh } \\
\hline & & $\begin{array}{c}\text { Before } \\
\text { treatment, } \\
n=15\end{array}$ & $\begin{array}{c}\text { After } 3 \text { month } \\
\text { treatment, } \\
n=12\end{array}$ & $\begin{array}{c}\text { Before } \\
\text { treatment, } \\
n=15\end{array}$ & $\begin{array}{l}\text { After } 3 \text { month } \\
\text { treatment, } n=15\end{array}$ \\
\hline Adiponectin, $\mu \mathrm{g} / \mathrm{ml}$ & $8.46 \pm 0.11$ & $15.78 \pm 0.98^{\circ}$ & $17.91 \pm 0.75^{\#}$ & $16.12 \pm 0.79^{\bullet}$ & $12.82 \pm 0.84^{\star}$ \\
\hline Leptin, ng/ml & $7.92 \pm 0.28$ & $6.73 \pm 0.37^{\bullet}$ & $5.21 \pm 0.11^{\#}$ & $6.81 \pm 0.13^{\bullet}$ & $7.15 \pm 0.16$ \\
\hline IRI, mcod/I & $5.89 \pm 0.32$ & $26.53 \pm 1.87^{\star}$ & $28.32 \pm 1.54^{\star \#}$ & $26.89 \pm 1.75^{\star \bullet}$ & $19.61 \pm 1.49 *$ \\
\hline HOMA-IR & $1.05 \pm 0.06$ & $7.08 \pm 0.16^{\star \bullet}$ & $7.42 \pm 0.13^{\star \#}$ & $7.11 \pm 0.17^{\star \bullet}$ & $4.26 \pm 0.11^{*}$ \\
\hline QUICKI & $0.681 \pm 0.004$ & $0.348 \pm 0.003^{*}$ & $0.345 \pm 0.004^{\star \#}$ & $0.349 \pm 0.003^{\star \bullet}$ & $0.526 \pm 0.005^{\star}$ \\
\hline HbA1c, \% & $4.63 \pm 0.18$ & $5.92 \pm 0.24$ & $6.12 \pm 0.14^{\#}$ & $5.89 \pm 0.26^{\bullet}$ & $5.32 \pm 0.14$ \\
\hline Child-Pugh score & - & $13.98 \pm 0.61^{* \bullet}$ & $15.38 \pm 0.52^{\star \#}$ & $14.21 \pm 0.64^{\star \bullet}$ & $7.84 \pm 0.41$ \\
\hline MELD score & - & $27.43 \pm 1.19^{\star \bullet}$ & $30.13 \pm 1.21^{\text {*\# }}$ & $28.13 \pm 1.23^{\star \bullet}$ & $17.52 \pm 1.15$ \\
\hline
\end{tabular}

Continuation of Table 3

\begin{tabular}{|c|c|c|c|c|c|}
\hline \multirow[b]{3}{*}{ Values } & \multirow{3}{*}{$\begin{array}{c}\text { Control, } \\
n=20\end{array}$} & \multicolumn{4}{|c|}{ ALC } \\
\hline & & \multicolumn{2}{|c|}{$\mathrm{IICb}$} & \multicolumn{2}{|c|}{$\mathrm{IICh}$} \\
\hline & & $\begin{array}{c}\text { Before } \\
\text { treatment, } \\
n=16\end{array}$ & $\begin{array}{c}\text { After } 3 \text { month } \\
\text { treatment, } \\
n=14\end{array}$ & $\begin{array}{c}\text { Before } \\
\text { treatment, } \\
n=15\end{array}$ & $\begin{array}{l}\text { After } 3 \text { month } \\
\text { treatment, } n=15\end{array}$ \\
\hline Adiponectin, $\mu \mathrm{g} / \mathrm{ml}$ & $8.46 \pm 0.11$ & $15.86 \pm 0.67$ & $17.84 \pm 1.05^{\#}$ & $15.81 \pm 0.93^{\bullet}$ & $10.13 \pm 0.74$ \\
\hline Leptin, ng/ml & $7.92 \pm 0.28$ & $6.78 \pm 0.19$ & $5.17 \pm 0.13^{\#}$ & $6.69 \pm 0.24^{\bullet}$ & $7.09 \pm 0.11$ \\
\hline IRI, mcod/I & $5.89 \pm 0.32$ & $6.75 \pm 0.36$ & $6.97 \pm 0.24^{\#}$ & $6.85 \pm 0.23^{\bullet}$ & $6.33 \pm 0.26$ \\
\hline HOMA-IR & $1.05 \pm 0.06$ & $2.18 \pm 0.09$ & $2.35 \pm 0.12^{\#}$ & $2.23 \pm 0.10^{\bullet}$ & $1.98 \pm 0.09$ \\
\hline QUICKI & $0.681 \pm 0.004$ & $0.427 \pm 0.003$ & $0.419 \pm 0.004^{\#}$ & $0.425 \pm 0.003^{\bullet}$ & $0.539 \pm 0.005$ \\
\hline $\mathrm{HbA1c}, \%$ & $4.63 \pm 0.18$ & $5.85 \pm 0.19$ & $5.91 \pm 0.16^{\#}$ & $5.87 \pm 0.21^{\bullet}$ & $5.16 \pm 0.18$ \\
\hline Child-Pugh score & - & $12.52 \pm 0.67^{\bullet}$ & $13.97 \pm 0.65^{\#}$ & $12.81 \pm 0.53^{\circ}$ & $7.44 \pm 0.38$ \\
\hline MELD score & - & $23.65 \pm 1.02^{\bullet}$ & $25.43 \pm 1.26^{\#}$ & $23.71 \pm 1.11^{\bullet}$ & $16.83 \pm 1.18$ \\
\hline
\end{tabular}

Notes.

1. * - probability of difference of values between groups I and II $(p<0.05)$.

2. - probability of differences of values before and after treatment $(p<0.05)$

3. ${ }^{*}$ - probability of differences of values between groups $A$ and Ah with treatment protocols $(p<0.05)$. 
of group ICb liver failure was developed, 1 patient of group $\mathrm{ICb}$ group had mesenteric thrombosis, 1 patient of group $\mathrm{IICb}$ had bleeding from varicose veins).

In patients of groups I and II who received the $\mathrm{h}$ protocol, at the stage of compensation, subcompensation and decompensation, the indicators of carbohydrate metabolism, adiponectin and leptin significantly improved $(p<0.05)$. In patients of groups I and II who received basic treatment, at the stage of compensation such indicators worsened, but no significant difference was observed before and after the treatment $(p>0.05)$. In patients of group I who received basic treatment, significantly worsened carbohydrate metabolism, adiponectin and leptin at the stage of subcompensation $(p<0.05)$, and in patients of group II no significant difference before and after treatment was observed $(p>0.05)$. In patients of group I receiving basic treatment, at the stage of decompensation the indicators of HOMAIR, adiponectin and leptin significantly deteriorated $(p<0.05)$, other indicators of carbohydrate metabolism deteriorated, but there was no significant difference before and after treatment ( $p>0.05)$. In patients of group II who received basic treatment, at the stage of decompensation carbohydrate metabolism, adiponectin and leptin values deteriorated, but no significant difference was observed before and after treatment $(p>0.05)$.

Significant deterioration in indicators of carbohydrate metabolism, adiponectin and leptin in patients receiving basic treatment was accompanied by deterioration of their condition and increased the risk of 3-month mortality.

In this study, the values of carbohydrate metabolism, adiponectin and leptin were used to evaluate the effectiveness of a three-month treatment regimen with ademethionine and arginine glutamate in patients with ALC in combination with obesity. Obese patients with ALC have a more severe course of the disease, accompanied by more pronounced clinical manifestations, impaired carbohydrate metabolism and imbalance of leptin and adiponectin levels.

Changes in carbohydrate metabolism were characterized by a significant increase in IRI, HOMA-IR index and decrease in QUICKI index in patients of group I compared with patients of group II. The HbA1c index was significantly increased at the stage of compensation and subcompensation in patients of group I compared with patients of group II $(p<0.05)$, but at the stage of decompensation no significant difference was observed ( $p>0.05)$. The detected changes in carbohydrate metabolism indicate that patients in group I have insulin resistance. Elevated levels of HbA1c and IRI were found in group II patients at the decompensation stage, which is probably due to the direct involvement of the liver in carbohydrate metabolism.

The peculiarity of adipocytokine parameters was that with the progression of LC the level of leptin decreased and the level of adiponectin increased. Resistance to leptin is associated with adipose tissue as an endocrine organ and is characteristic of overweight people, which is confirmed by higher levels of leptin in patients of group I. Higher leptin content in class A and B patients is accompanied not only by impaired liver function, but also increased its release from adipose tissue. In class C patients, fat depots are depleted, that's why leptin levels are reduced. Moreover, this decrease correlates with the severity of the disease and the prognostic MELD score. Adiponectin levels were decreased in class A patients and increased in patients with more severe course of the disease and correlated with disease severity and the MELD score. Due to the hepatoprotective effect of adiponectin, some scientists believe that its increased level reflects the anti-inflammatory response to liver damage, which depends on the severity of the disease.

An analysis of the relationship between leptin and adiponectin levels and carbohydrate metabolism showed that a stronger correlation was observed in patients with ALC combined with obesity. The identified correlations between leptin and adiponectin levels with the severity of LC and the MELD score allow us to consider their changes for assessment of the severity of LC and prediction of the course of the disease.

The inclusion of ademethionine and arginine glutamate in the treatment regimen for 3 months allowed to improve the general condition of patients, their clinical and laboratory parameters and reduce the rate of disease progression, which is reflected in improved carbohydrate metabolism, leptin and adiponectin and reduced indicators of the severity scale according to Child-Pugh and the 3-month MELD mortality score.

CONCLUSIONS. Progression of liver cirrhosis in patients with ALC in combination with obesity is accompanied by more severe clinical and laboratory manifestations. Changes in carbohydrate metabolism (IRI, HOMA-IR index, QUICKI index and $\mathrm{HbAlc}$ ) in patients with ALC combined with obesity indicate the presence of insulin resistance. Leptin and adiponectin levels in patients with ALC in combination with obesity correlate with changes in carbohydrate metabolism, the severity of LC and the prognostic MELD score, which allows them to be used to assess the severity and prediction of ALD in combination with obesity. Inclusion of ademethionine and arginine glutamate in the complex 
treatment of patients with ALC in combination with obesity helps to reduce insulin resistance, improve leptin and adiponectin. In patients with ALC in combination with obesity, the inclusion in the complex treatment of ademethionine and arginine glutamate helps to improve the course of the disease according to the indicators of the severity scale using the Child-Pugh and MELD scales.

\section{LIST OF LITERATURE}

1. A new definition for metabolic associated fatty liver disease: an international expert consensus statement / M. Eslam, P. N. Newsome, Q. M. Anstee [et al.] // Journal of Hepatology. -2020. DOI:10.1016/j.jhep.2020.03.039.

2. Diehl A. M. Cause, pathogenesis, and treatment of nonalcoholic steatohepatitis / A. M. Diehl, C. Day // New England Journal of Medicine. - 2017. - 377 (21). P. 2063-2072. DOI:10.1056/nejmra1503519.

3. Leptin as a key player in insulin resistance of liver cirrhosis? A cross-sectional study in liver transplant candidates / I. Košuta, A. Mrzljak, B. Kolarić [et al.] // Journal of Clinical Medicine. - 2020. - 9 (2). - P. 560. DOI:10.3390/jcm9020560.

4. The diagnosis and management of nonalcoholic fatty liver disease: Practice guidance from the American Association for the Study of Liver Diseases / N. Chalasani, Z. Younossi, J. E. Lavine [et al.] // Hepatology. - 2017. 67 (1). - P. 328-357. DOI:10.1002/hep.29367.

5. Eslam M. MAFLD: A consensus-driven proposed nomenclature for metabolic associated fatty liver disease / M.Eslam,A.J.Sanyal,J.George //Gastroenterology. - 2020. DOI:10.1053/j.gastro.2019.11.312.

6. Adipokines levels are associated with the severity of liver disease in patients with alcoholic cirrhosis / M. Kalafateli, C. Triantos, E. Tsochatzis [et al.] // World J. Gastroenterol. - 2015. - 21 (10). - P. 3020-3029. DOI: 10.3748/wjg.v21.i10.3020.

7. Antwi S. O. Racial, ethnic, and age disparities in incidence and survival of intrahepatic cholangiocarcinoma in the United States; 1995-2014/ S. O. Antwi, O. Y. Mousa, T. T. Patel // Annals of Hepatology. - 2018. - 17 (2). P. 274-285. DOI:10.5604/01.3001.0010.8659.

8. Possibilities of using MELD scale for determining hepatic cirrhosis degree of severity / S. V. Paducheva, I. A. Bulatova, A. P. Schekotova [et al.] // Perm Medical Journal. - 2017. - 34 (6). - P. 40-44. DOI 10.17816/ pmj34640\%44.

9. Circulating adiponectin levels in relation to carotid atherosclerotic plaque presence, ischemic stroke risk, andmortality:Asystematic review andmeta-analyses / J. Gorgui, K. Gasbarrino, M. K. Georgakis [et al.] // Metabolism. - 2017. - 69. - P. 51-66. DOI: 10.1016/j. metabol.2017.01.002.

10. Correlation between nonalcoholic fatty liver disease features and levels of adipokines and inflammatory cytokines among morbidly obese individuals / L. Baltieri,

\section{REFERENCES}

1. Eslam, M., Newsome, P.N., Anstee, Q.M., Targher, G., Gomez, M.R., Zelber-Sagi, S. et al. (2020). A new definition for metabolic associated fatty liver disease: An international expert consensus statement. Journal of Hepatology. DOI:10.1016/j.jhep.2020.03.039.
E. A. Chaim, F. D. M. Chaim [et al.] // Arq. Gastroenterol. 2018. - 55 (3). - P. 247-251. DOI: 10.1590/S00042803.201800000-62.

11. Polyzos S. A. Adipokines in nonalcoholic fatty liver disease / S. A. Polyzos, J. Kountourasa, C. S. Mantzoros // Metabolism. - 2016. - 65 (8). - P. 1062-1079. DOI: 10.1016/j.metabol.2015.11.006.

12. Jamali $\mathrm{R}$. The correlation between serum adipokines and liver cell damage in non-alcoholic fatty liver disease / R. Jamali, N. Hatami, F. Kosari // Hepat. Mon. - 2016. - 16 (5). - P. e37412. DOI: 10.5812/hepatmon.37412.

13. Metabolic aspects of adult patients with nonalcoholic fatty liver disease / L. Abenavoli, N. Milic, L. Di Renzo [et al.] // World J. Gastroenterol. - 2016. - 22. P. 7006-7016. DOI: 10.3748/wjg.v22.i31.7006.

14. Adipokines in liver cirrhosis / C. Buechler, E. Haberl, L. Rein-Fischboeck L, C. Aslanidis // International Journal of Mollecular Sciences. - 2017. - 18 (7). P. 1392. DOI: 10.3390/ijms18071392.

15. Boutari C. Association of adipokines with development and progression of nonalcoholic fatty liver disease / C. Boutari, N. Perakakis, C. S. Mantzoros // Endocrinol. Metab. - 2018. - 33 (1). - P. 33-43. DOI: 10.3803/EnM.2018.33.1.33.

16. Adipokines and non-alcoholic fatty liver disease: Multiple interactions / T. E. Adolph, C. Grander, F. Grabherr, H. Tilg // Int. J. Mol. Sci. - 2017. - 18. - P. 1649. DOI: $10.3390 / \mathrm{ijms} 18081649$.

17. Novel plasma biomarkers associated with liver disease severity in adults with nonalcoholic fatty liver disease / V. Ajmera, E. R. Perito, N. M. Bass // Hepatology. - 2017. - 65 (1). - P. 65-77. DOI:10.1002/ hep.28776.

18. Serum adipokines might predict liver histology findings in non-alcoholic fatty liver disease / R. Jamali, M. Razavizade, A. Arj, M. H. Aarabi // World J. Gastroenterol. - 2016. - 22 (21). - P. 5096-5103. DOI: 10.3748/ wjg.v22.i21.5096.

19. Recent advances in understanding the role of adipocytokines during non-alcoholic fatty liver disease pathogenesis and their link with hepatokines / N. Panera, C. Della Corte, A. Crudele [et al.] // Expert Review of Gastroenterology \& Hepatology. - 2015. - 10 (3). P. 393-403. DOI: 10.1586/17474124.2016.1110485.

2. Diehl, A.M., \& Day, C. (2017). Cause, pathogenesis, and treatment of nonalcoholic steatohepatitis. New England Journal of Medicine, 377 (21), 2063-2072. DOI:10.1056/nejmra1503519. 
3. Košuta, I., Mrzljak, A., Kolarić, B., \& Vučić Lovrenčić, M. (2020). Leptin as a key player in insulin resistance of liver cirrhosis? A cross-sectional study in liver transplant candidates. Journal of Clinical Medicine, 9 (2), 560. DOI:10.3390/jcm9020560.

4. Chalasani, N., Younossi, Z., Lavine, J. E., Charlton, M., Cusi, K., Rinella, M., ... Sanyal, A. J. (2017). The diagnosis and management of nonalcoholic fatty liver disease: Practice guidance from the American Association for the Study of Liver Diseases. Hepatology, 67 (1), 328-357. DOI:10.1002/hep.29367.

5. Eslam, M., Sanyal, A. J., \& George, J. (2020). MAFLD: A consensus-driven proposed nomenclature for metabolic associated fatty liver disease. Gastroenterology. DOI:10.1053/j.gastro.2019.11.312.

6. Kalafateli, M., Triantos, C., Tsochatzis, E., Michalaki, M., Koutroumpakis, E., Thomopoulos, K. et al. (2015). Adipokines levels are associated with the severity of liver disease in patients with alcoholic cirrhosis. World J. Gastroenterol., 21 (10), 3020-3029. DOI: 10.3748/wjg. v21.i10.3020.

7. Antwi, S.O., Mousa, O.Y., \& Patel, T. (2018). Racial, ethnic, and age disparities in incidence and survival of intrahepatic cholangiocarcinoma in the United States; 1995-2014. Annals of Hepatology, 17 (2), 274-285. DOI:10.5604/01.3001.0010.8659.

8. Paducheva, S.V., Bulatova, I.A., Schekotova, A.P., Tretyakova, Y.I., \& Schekotova, I.V. (2017). Possibilities of using MELD scale for determining hepatic cirrhosis degree of severity. Perm Medical Journal, 34 (6), 40-44. DOI: 10.17816/pmj34640\%44.

9. Gorgui, J., Gasbarrino, K., Georgakis, M.K., Karalexi, M.A., Nauchec, B., Petridou, E.T. et al. (2017). Circulating adiponectin levels in relation to carotid atherosclerotic plaque presence, ischemic stroke risk, andmortality:Asystematic review andmeta-analyses. Metabolism, 69, 51-66. DOI: 10.1016/j.metabol.2017.01.002.

10. Baltieri, L., Chaim, E.A., Chaim, F.D.M., Utrini, M.P., Gestic, M.A., \& Cazzo, E. (2018). Correlation between nonalcoholic fatty liver disease features and levels of adipokines and inflammatory cytokines among morbidly obese individuals. Arq. Gastroenterol., 55 (3), 247-251. DOI: 10.1590/S0004-2803.201800000-62.
11. Polyzos, S.A., Kountourasa, J., \& Mantzoros, C.S. (2016). Adipokines in nonalcoholic fatty liver disease. Metabolism, 65 (8), 1062-1079. DOI: 10.1016/j.metabol.2015.11.006.

12. Jamali, R., Hatami, N., \& Kosari, F. (2016). The correlation between serum adipokines and liver cell damage in non-alcoholic fatty liver disease. Hepat. Mon., 16 (5), e37412. DOI: 10.5812/hepatmon.37412.

13. Abenavoli, L., Milic, N., Di Renzo, L., Preveden, T., Medić-Stojanoska, M., \& De Lorenzo, A. (2016). Metabolic aspects of adult patients with nonalcoholic fatty liver disease. World J. Gastroenterol., 22, 7006-7016. DOI: 10.3748/wjg.v22.i31.7006.

14. Buechler, C., Haberl, E., Rein-Fischboeck, L., \& Aslanidis, C. (2017). Adipokines in liver cirrhosis. International Journal of Mollecular Sciences, 18 (7), 1392. DOI: $10.3390 / \mathrm{ijms} 18071392$.

15. Boutari, C., Perakakis, N., \& Mantzoros, C.S. (2018). Association of adipokines with development and progression of nonalcoholic fatty liver disease. Endocrinol. Metab., 33 (1), 33-43. DOI: 10.3803/EnM.2018.33.1.33.

16. Adolph, T.E., Grander, C., Grabherr, F., \& Tilg, H. (2017). Adipokines and non-alcoholic fatty liver disease: Multiple interactions. Int. J. Mol. Sci., 18, 1649. DOI: $10.3390 / \mathrm{jjms} 18081649$.

17. Ajmera, V., Perito, E.R., Bass, N.M., Terrault, N.A., Yates, K.P., Gill, R. et al. (2017). Novel plasma biomarkers associated with liver disease severity in adults with nonalcoholic fatty liver disease. Hepatology, 65 (1), 65-77. DOI:10.1002/hep.28776.

18. Jamali, R., Razavizade, M., Arj, A., \& Aarabi, M.H. (2016). Serum adipokines might predict liver histology findings in non-alcoholic fatty liver disease. World $\mathrm{J}$. Gastroenterol., 22 (21), 5096-5103. DOI: 10.3748/wjg. v22.i21.5096.

19. Panera, N., Della Corte, C., Crudele, A., Stronati, L., Nobili, V., \& Alisi, A. (2015). Recent advances in understanding the role of adipocytokines during nonalcoholic fatty liver disease pathogenesis and their link with hepatokines. Expert Review of Gastroenterology \& Hepatology, 10 (3), 393-403. DOI: 10.1586/17474124. 2016.1110485.

Н. Р. Матковська ІВАНО-ФРАНКІВСЬКИЙ НАЦІОНАЛЬНИЙ МЕДИЧНИЙ УНІВЕРСИТЕТ МОЗ УКРАЇНИ

\section{ЗМІНИ ПОКАЗНИКІВ ВУГЛЕВОДНОГО ОБМІНУ ТА АДИПОЦИТОКІНІВ ПІД ВПЛИВОМ ЛІКУВАННЯ ХВОРИХ НА АЛКОГОЛЬНИЙ ЦИРОЗ ПЕЧІНКИ В ПОЄДНАННІ 3 ОЖИРІННЯМ 3 ВИКОРИСТАННЯМ АДЕМЕТІОНІНУ Й АРГІНІНУ ГЛУТАМАТУ}

\section{Резюме}

Вступ. Цироз печінки, що зумовлений зловживанням алкоголю, є однією з провідних причин госпіталізації і втрати працездатності пацієнтами із захворюваннями органів шлунково-кишкового тракту.

Мета дослідження - вивчити ефективність лікування хворих на алкогольний цироз печінки (АЦП) у поєднанні з ожирінням залежно від стадії декомпенсації з використанням адеметіоніну й аргініну глутамату.

Методи дослідження. У дослідженні взяли участь 215 хворих з діагностованим алкогольним цирозом печінки, серед яких було 66 жінок та 149 чоловіків. У 109 осіб діагностовано АЦП з ожирінням, у 106 осіб АЦП без ожиріння. Пацієнтів поділили на підгрупи залежно від стадії декомпенсації за Чайльдом - П'ю, а також залежно від застосованого протоколу лікування (b протокол - базова терапія, $h$ протокол - базова терапія в поєднанні з адеметіоніном й аргініну глутаматом). 
Результати й обговорення. У чій роботі для оцінки ефрективності тримісячної схеми лікування 3 включенням адеметіоніну й аргініну глутамату у хворих на АЦП у поєднанні з ожирінням використано показники вуглеводного обміну, адипонектину та лептину. В пацієнтів з АЦП у поєднанні з ожирінням спостерігали тяжчий перебіг захворювання, що супроводжувалося більш вираженими клінічними проявами, порушенням вуглеводного обміну і дисбалансом рівнів лептину та адипонектину. Включення в схему лікування адеметіоніну й аргініну глутамату дозволило покращити загальний стан пацієнтів, клініко-лабораторні показники і зменшити темпи прогресування захворювання, про що свідчили поліпшення показників вуглеводного обміну, лептину й адипонектину і зниження показників шкали тяжкості Чайльда - П'ю та індексу тримісячної летальності MELD.

Висновки. Включення в комплексне лікування хворих на АЦП у поєднанні з ожирінням адеметіоніну й аргініну глутамату сприяє зменшенню інсулінорезистентності, покращенню показників лептину та адипонектину. Використання в комплексному лікуванні пацієнтів з АЦПу поєднанні з ожирінням адеметіоніну й аргініну глутамату сприяє поліпшенню перебігу захворювання за показниками шкали тяжкості Чайльда - П'ю та індексу MELD.

КЛЮЧОВІ СЛОВА: алкогольна хвороба печінки; цироз печінки; ожиріння; адипоцитокіни; вуглеводний обмін.

\author{
ИВАНО-ФРАНКОВСКИЙ НАЦИОНАЛЬНЫЙ МЕДИЦИНСКИЙ УНИВЕРСИТЕТ МОЗ УКРАИНЫ
}

\title{
ИЗМЕНЕНИЯ ПОКАЗАТЕЛЕЙ УГЛЕВОДНОГО ОБМЕНА И АДИПОЦИТОКИНОВ ПОД ВЛИЯНИЕМ ЛЕЧЕНИЯ БОЛЬНЫХ АЛКОГОЛЬНЫМ ЦИРРОЗОМ ПЕЧЕНИ В СОЧЕТАНИИ С ОЖИРЕНИЕМ С ИСПОЛЬЗОВАНИЕМ АДЕМЕТИОНИНА И АРГИНИНА ГЛУТАМАТА
}

\section{Резюме}

Вступление. Цирроз печени, обусловленный злоупотреблением алкоголя, является одной из ведущих причин госпитализации и потери трудоспособности пациентами с заболеваниями органов желудочно-кишечного тракта.

Цель исследования - изучить эфрфективность лечения больных алкогольным циррозом печени (АЦП) в сочетании с ожирением в зависимости от стадии декомпенсации с использованием адеметионина и аргинина глутамата.

Методы исследования. В исследовании приняли участие 215 больных с диагностированным алкогольным циррозом печени, среди которых было 66 женщин и 149 мужчин. В 109 лиц диагностирован АЦП с ожирением, в 106 лиц - АЦП без ожирения. Пациентов разделили на подгруппы в зависимости от cmaдии декомпенсации по Чайльду - Пью, а также в зависимости от примененного протокола лечения ( $b$ протокол - базовая терапия, $h$ протокол - базовая терапия в сочетании с адеметионином и аргинина глутаматом).

Результаты и обсуждение. В этой работе для оценки эффрективности трехмесячной схемы лечения с включением адеметионина и аргинина глутамата у больных АЦП в сочетании с ожирением использовано показатели углеводного обмена, адипонектина и лептина. У пациентов с АЦП в сочетании с ожирением наблюдали более тяжелое течение заболевания, что сопровождалось более выраженными клиническими проявлениями, нарушением углеводного обмена и дисбалансом уровней лептина и адипонектина. Включение в схему лечения адеметионина и аргинина глутамата позволило улучшить общее состояние пациентов, клинико-лабораторные показатели и уменьшить темпы прогрессирования заболевания, о чем свидетельствовали улучшение показателей углеводного обмена, лептина и адипонектина и снижение показателей шкалы тяжести Чайльда - Пью и индекса трехмесячной летальности MELD.

Выводы. Включение в комплексное лечение больных АЦП в сочетании с ожирением адеметионина и аргинина глутамата способствует уменьшению инсулинорезистентности, улучшению показателей лептина и адипонектина. Использование в комплексном лечении пациентов с АЦП в сочетании с ожирением адеметионина и аргинина глутамата способствует улучшению течения заболевания по показателям шкалы тяжести Чайльда - Пью и индекса MELD.

КЛЮЧЕВЫЕ СЛОВА: алкогольная болезнь печени; цирроз печени; ожирение; адипоцитокины; углеводный обмен.

Received 02.09.20

Address for correspondence: N. R. Matkovska, Ivano-Frankivsk National Medical University, Ministry of Health of Ukraine, Kropyvnytskyi 16 St., Ivano-Frankivsk, 76018, Ukraine, e-mail: nmail4you@gmail.com. 